$\overbrace{\text { KRISTIANSTAD }}^{\text {de }}$

UNIVERSITY COLLEGE

\section{Department of Business Studies}

\author{
Working Paper Series \\ ISSN:1650-0636
}

Working Paper Series 2007:4

\title{
Consolidated financial reports in local government: a comparative analysis of IPSASB and SCMA
}

Grossi, G. \& Tagesson, T.

\begin{abstract}
Municipal and local governments seem to use other entities to a larger extent to organise and co-ordinate their activities. Thus the need and demand for consolidated financial statements has been observed in several countries as well as by international standard-setters such as the International Public Sector Accounting Standards Board (IPSASB). Sweden introduced consolidated financial statements in municipalities and local governments in the 1980 s and is one of the few countries where consolidated financial statements for municipalities and local governments are fully implemented. The aim of this study is to analyse similarities and differences in the approach to consolidated financial statements in standards issued by the IPSASB and the Swedish Council for Municipal Accounting (SCMA). The analysis is based on data from documentary studies and interviews. The results show that the two standard-setters approach the problem of consolidation quite differently. While the IPSASB seems to emphasise decision-making, the SCMA accentuates accountability. As a result, the standard-setters come to different conclusions about such matters as concept of control, valuation and methods of consolidation.
\end{abstract}

Department of Business Studies

Kristianstad University College

SE-291 88 KRISTIANSTAD

SWEDEN

Phone: +46 44-20 3106
Fax: +46 4644203103
http://www.hkr.se/templates/Page__1011.aspx
e-mail: $\underline{\text { e@ hkr.se }}$




\section{Introduction}

During the last few decades public sector organisations in many countries have introduced accrual accounting including consolidated accounting (e.g. Lüder and Jones, 2003; Stalebrink and Sacco, 2006). In many countries also international auditing and consulting firms have played a crucial role in the process of implementing accrual accounting in the public sector (Lüder and Jones, 2003; Christensen, 2005). Methods and practices from the private sector have been copied and introduced in the public sector without any thorough analysis of the objectives and characteristics of the latter (Christiaens, 2002). According to Christiaens, the uncritical introduction of private sector accounting methods and the apparent lack of a conceptual framework for governmental accounting creates problems rather than resolving them.

The shift from cash to accrual reporting represents a major development in public sector financial reporting. Broadbent and Guthrie (1992) described this paradigm shift as new accounting and associated it with a move in the public sector towards managerialism. Hopwood (1984) associated the use of accrual accounting with government decisions to induce efficiencies into public institutions. Aiken and McCrae (1992), however, cautioned about the potential risk of welfare or other policy distortions that might be caused by the inappropriate application of accrual accounting outside competitive markets.

Changing from a cash basis to an accrual basis of accounting has implications for many features of public sector accounting and financial reporting, one of which is the use of accrual-based consolidated financial reporting. While the simple aggregation of cash-based data of individual entities will result in a form of consolidated report, the accrual-based method of consolidated financial reporting includes adjustments designed to eliminate doublecounting of data where inter-entity transactions have occurred (Wise, 2004).

The development of municipal corporations has led to the observation that annual accounts of local governments disclose only a partial view of their economic and financial activities. This is because the financial consequences of subsidiaries, joint ventures and associates are not necessarily included in the annual reports of the local governments. Thus, the decentralisation process has resulted in a great lack of information (Walsh, 1994). Consequently, accountability and decision usefulness of local governments is no longer guaranteed by their annual accounts. Internal users (e.g. politicians, managers, employees) and external users 
(e.g. citizens, voters, taxpayers, suppliers, other public administrations, banks) of financial information are not able to base their decisions on reliable and relevant information about the financial position, financial performance and cash flows of the local government entity (Hughes, 1994). Consolidation is a necessary step to overcome this information gap (Lande, 1998; Grossi, 2001, 2004; Srocke, 2004; Wise, 2004, 2006).

In the private sector, consolidated financial statements are useful accounting instruments that improve accountability and provide an overall true and fair view of assets/liabilities and financial results (profit/loss) of the group (Childs, 1949; Walker, 1978). In the public sector, the consolidated financial statement is a useful instrument for governments that deal with a large number of publicly-owned companies because it presents a clear picture of the current economic status and functioning of the municipal corporate group (Lande, 1998; Grossi, 2001, 2004; Srocke, 2004; Wise, 2004, 2006; Grossi and Srocke, 2005). Such information is not ascertainable just by reading and analysing the single annual reports published by each company. However, this does not mean that the accounting documents drafted by local governments or by the companies that are a part of the municipal corporate group (which have their own objectives in terms of information and data) are any less important. The methodology used to gather information for the consolidated financial statement is still accrual accounting and thus must be implemented in a uniform way in all entities belonging to the municipal corporate group, as well as in local government itself.

However, the stimuli behind these accounting reforms and the key factors in the reform process have varied among different countries (e.g. Lüder and Jones, 2003). In Sweden, an early adopter of both accrual accounting and consolidated accounting in the municipal sector, the Swedish Federation of Local Authorities and representatives from the academy played a critical role in the introduction and shaping of the reform process (e.g. Bergevärn, Mellemvik and Olson, 1995; Mattisson, Paulsson and Tagesson, 2003). Academics played a particularly crucial role in the introduction and implementation of consolidated reporting (Svenska Kommunforbundet, 1989; Bergevärn, Mellemvik and Olson, 1995).

The aim of this study is to critically analyse similarities and differences in the approach to consolidated financial statements in standards issued by the International Public Sector Accounting Standards Board (IPSASB) and the Swedish Council for Municipal Accounting (SCMA). Sweden, as an early adopter, is an interesting case since the regulation of 
consolidated reporting in municipalities took place even before accounting in the private sector began significantly to be influenced and harmonised with international accounting standards.

\section{Theoretical framework}

The identification and definition of the accounting entity is dependent on the area of economic interest to identified stakeholders (Eriksson, 2002). Stakeholders might have different needs and uses for accounting information. Hence, a stakeholder identified as a primary user of accounting information can be expected to influence not only accounting issues such as valuation and reporting, but also the determination and definition of the accounting entity and methods of consolidating group accounts. Clearly, in order to determine the accounting goals, stakeholders' needs and uses of accounting information must be understood (e.g. Daniels and Daniels, 1991).

The role of accounting in providing investors with information for decision making has a long history in accounting theory. For instance, Moonitz (1961) stated that accounting information had to be useful for investors. This idea was the basis of the decision-making approach (AICPA, 1973) which is the foundation of the conceptual frameworks of both FASB and, later, IASB. However, investors are not the only possible stakeholders and accounting is more than an instrument for decision making. In the public sector, accounting plays a crucial role in demonstrating accountability (Pallot, 1992; Coy et al., 2001; Chan, 2003; Mack and Ryan, 2006). According to the accountability approach (e.g. Ijiri, 1975), accounting is central in the control and balance of interest between agents and principals. Stanton et al. (1998) demonstrate how accounting information varies depending on whether accountability or decision making is emphasised. According to Demski et al. (2002), there is a tension between decision making and control ' $\ldots$ because the data and processes that help to establish control are not necessarily the best for decision making, and the same is true in reverse'. Ijiri (1975) applies a completely different meaning to the concepts of relevance and reliability than FASB does (Artsberg, 1992).

So, simply put: Different stakeholders may emphasise different aspects of accounting. Thus, the substance and form of the accounting could be expected to differ, depending on which group of individuals and stakeholders has the strongest influence and interest in the various aspects. 
Financing, legal form and purpose of the organisation are all aspects that influence the conditions and need for accounting information. In the preparatory work for the Swedish Municipal Accounting Act, the legislators outlined some specific aspects that they saw as influencing the accounting model and motivating particular piece of legislation for municipal accounting. Brorström, Haglund and Solli (2005) summarise these arguments as follows:

- Municipalities run operations in the public interest which are mainly financed by taxes and grants from central government. Production means such as fixed assets normally have the character of a public utility, which means that they are not realizable on a market.

- All obligations are secured by the municipalities' power of taxation.

- The activities of municipalities are regulated by legislation. The activities are supposed to be in the public interest. Hence, municipalities are generally prevented from running operations for the purpose of profit.

- Municipal revenues are not assignable to a consumer market; consequently, in the short-term perspective they are relatively unaffected by changes in expenses.

- A municipality cannot go bankrupt, since its position is guaranteed by the Swedish Constitution.

- The form of government is built upon the principles of representative democracy, including the political responsibilities of the elected representatives. The form of government is established on the principle of openness, that is, all documents and the bases for decisions are public records.

- The budget plays a crucial role in the formulation of goals, priorities and resource allocation. Budgetary decisions are central parts of the management of municipalities, as they are politically governed organisations.

These aspects are not specific only to the Swedish situation. Similar arguments are emphasised by Pallot (1992) in her argument for an accountability-based framework for public sector accounting. Jones and Pendlebury (2004) also stress that the obligations are secured by the power of taxation. Many authors point to the fact that public sector activities are budget-controlled and that the accounting information principally is used in the follow-up of the budget (Daniels and Daniels, 1991; Alijarde, 1997; Dittenhofer, 2001; Chan, 2003). 
According to the Governmental Accounting Standards Board, the objective of governmental financial accounting is to provide financial information '...that is useful for economic, social and political decisions' (GASB, 1987). Thus, the objectives of governmental accounting are different from and broader than the objectives of private sector accounting. Surplus and earnings are not even long-term goals in the public sector; the goal is rather to offer services to the citizens (Jones and Pendlebury, 2000; Dittenhofer, 2001). Moreover, large financial surpluses are considered 'bad'; they signal political irresponsibility and imposition of too high taxes (Anthony, 1985; Gosling, 1992).

It is not only objectives that differ between public and private sectors. Another characteristic of public sector accounting is the diversity and heterogeneity of the principals (Stalebrink and Sacco, 2006). A resident in a municipality is not only an 'owner' but also a 'customer' (Grönlund, Tagesson and Öhman, 2005). Besides residents and voters, there are other principals such as central government, creditors/investors (GASB, 1999), sister organizations such as other municipalities (Coy et al., 1997; Mack and Ryan, 2006) and internal users such as officials and politicians (Mack and Ryan, 2006).

Even though citizens and other stakeholders often lack direct interest in municipal accounting matters (Zimmerman, 1977; Alijarde, 1997; Coy et al., 1997; Bouckaert and Dooren, 2003), municipal accounting is an important part of the democratic system (GASB, 1987; Edström et al., 2004). Voters and taxpayers have a 'right to know' (GASB, 1987) and must be regarded as the primary stakeholders of municipal accounting (Daniels and Daniels, 1991). Therefore, accounting is an important tool to create political accountability in the democratic system:

The accounting system can be highly useful to the accountor and the accountee even if no one reads the accounting reports. Like insurance, what is ultimately of use here is the assurance provided by an accounting system of records and reports that things can be accounted for whenever necessary. (Ijiri, 1983:78)

In sum: Compared to the private sector, the public sector differs in organisational goals, financing, ownership, recipients of accounting information, etc. Considering these aspects, the decision-making approach does not seem to be so relevant for public sector accounting. We argue that an accountability approach (e.g. Ijiri 1975, 1983) would much better serve the objectives and needs of public sector accounting (Pallot, 1992; Mack and Ryan, 2006). This 
will be an important theme as we proceed to analyse the approach of consolidated financial statements in standards issued by the IPSASB and the Swedish Council for Municipal Accounting (SCMA).

\section{Data collection}

The analysis is primarily based on documentary studies. Besides the accounting standards on consolidated reporting issued by the IPSASB and SCMA, we also analysed statements, discussion papers, instruction manuals, annual reports and other documents regarding accrual accounting and consolidated reporting in municipalities and local government. In addition to the study of documents we had the opportunity to participate and observe the meetings of the SCMA's expert committee over a period of three years; these observations particularly helped us to better understand and interpret the data from the documents.

\section{The concept of control and method of consolidation according to IPSASB and SCMA}

\section{Consolidated reporting in Swedish municipalities}

Consolidated reporting was introduced on a voluntary basis in the late 1980s. The Swedish Federation of Local Authorities encouraged the introduction of consolidated reporting and in 1989 published a booklet with instructions and ideas about objectives and techniques for consolidated reporting in a municipal context. This booklet was prepared in co-operation with Dr. Lennart Eriksson from Gothenburg University, one of the leading scholars in the field of consolidated reporting. The basic ideas in this booklet still dominate praxis as well as standards in the field of consolidated reporting within the municipal sector. The Municipal Act of 1992 introduced a requirement that municipalities' annual reports should include a consolidated financial statement. In connection with the statutory requirement of consolidated reporting, the standard-setter of that time, the Swedish Federation of Local Authorities'

Reference Group in Accounting Issues [Referensgruppen i redovisningsfrågor], issued Standard 7 on consolidated reporting.

From 1998 municipal sector accounting has been regulated by a special law, the Municipal Accounting Act. According to this act, municipalities should establish a consolidated accounting report including a balance sheet and an income statement. The legislation refers to GAAP and standard-setters in the more detailed issues about consolidation methods and concept of control. The SCMA, which took over the power of standard-setting for the 
municipal sector when the Municipal Accounting Act was introduced, issued a standard (RKR 8.1) which is essentially built upon the same fundamental presumptions as earlier standards and GAAP..

In the municipal consolidated group, wholly-owned companies are included as well as companies with joint ownership. Companies should be included in the consolidated reporting if the municipality directly or indirectly has a material/significant influence. A rule of thumb is that the municipality should control $20 \%$ of the number of votes. However, according to the standard, there are situations when the numbers of votes comes short of $20 \%$ but the ownership involves a materially economic commitment for the municipality. In these cases the company should be included in the consolidated accounting. Hence, it is the economic concept rather than the legal concept that decides whether a company should be consolidated or not (cf. Lefebvre and Lin, 1991). But this approach is from the municipalities' point of view. The standard also states that, besides the criteria of significant influence, the municipality should also consider whether a consolidation of a wholly- or jointly-owned company provides any material information, compared with the information that the municipality's annual report give.

The accounting principles of the municipality should guide the preparation of the consolidated accounting reports. As a general rule, the proportional method should be used when consolidating the companies. The standpoint is based on the fact that a full consolidation method may imply that a company that is jointly owned by (for example) two municipalities can only be included in the consolidated reporting of one of the municipalities. Considering the specific aspects of municipal operations (cf. Brorström, Haglund and Solli, 2005) this would, according to the standard-setter, not give a true and fair view of the consolidated accounting. As profit is not a goal for municipalities, the need for information in order to estimate ROA or similar earning measurements is not of importance. Instead, it is information about the costs for service delivery and the obligations for the municipality that is of importance for the consolidated financial statements.

Even if the general rule is the proportional method of consolidation for each company, the standard-setter allows one exception. If an intra-group has been consolidated with a full consolidation method and, due to time and cost reasons, it is not justifiable to consolidate each company one by one, it is acceptable to proceed from the intra-group's annual accounts even 
if it is prepared according to the full consolidation method. This alternative to the general rule has been criticised because it could mean that the consolidated annual accounts of the municipality become over- or underestimated depending on ownership structure (Falkman, 2005).

The main content of SCMA Standard 8.1 on consolidated reporting can be summarised as follows:

- It is the material information about the municipality's obligations rather than control that determines whether a company should be included in the consolidated reporting or not;

- The proportional method should be used when consolidating the companies.

\section{Consolidated reporting according to IPSASB}

In the private sector, the obligation to compile consolidated financial statements as well as the consolidation area itself will be defined according to the concept of control. If a company controls another company, the controlling organisation is obliged to present consolidated financial statements (IFRS 27). According to IAS 27, control is given if the parent is able to govern the financial and operating policies of another company. It does not matter if the parent actually uses the power to influence or if the parent benefits because of the influence, either in a positive or negative way. The ability to govern the financial and operating policies must be proved by a formal document like a statute, an agreement with the other investors or by reason of a majority of voting rights (IAS 27.12).

However, the definition of control used in the private sector does not satisfy the complexity of the public sector. This is because local governments aim to meet non-financial as well as financial objectives, whereas municipal corporate groups consist of heterogeneous, decentralised organisations. Therefore the definition of control must be changed in order to satisfy the special characteristics of the public sector.

The criteria that define control according to IPSAS 6 are the following:

- The local government benefits from the activities of the decentralised organisations;

- The local government has the power to govern the financial and operating policies of the decentralised organisations; and 
- The power to govern the financial and operating policies is presently exercisable. (IPSAS 6.36).

If all three criteria are met, the local government controls the other decentralised organisation, and there is an obligation to prepare consolidated financial statements.

In contrast to the private sector's definition of control, these criteria fix two elements of the definition: the 'benefit element' and the 'power element' (IPSAS 6.26). Both elements have to be considered. The benefit element signifies that the controlling entity has to receive a financial or non-financial benefit from the activities of the decentralised organisation. This can also be a financial risk (IPSAS 6.27). The power element signifies that the government or the parent of a subgroup must be able to exercise the power to govern the financial and operational policies of the decentralised organisation. This does not require a majority of voting rights, but the power must be conferred by law or another formal agreement. The formal agreement must presently exist. If the ability to exercise the power requires changing law or renegotiating agreements, the power is not presently exercisable. The existence of power to control does not mean that the controlling government or parent of a subgroup has to use this power. It is sufficient that the controlling entity is able to use it. It is possible that the controlling entity never gives any instruction to the decentralised organisations (IPSAS 6.28). Besides, the controlling entity is not required to have influence on the day-to-day business (IPSAS 6.29) (Grossi, 2004; Srocke, 2004).

Generally, every controlled entity should be consolidated (IPSAS 6.21). Only when '(a) control is intended to be temporary because the controlled entity is acquired and held exclusively with a view to its subsequent disposal in the near future; or (b) it operates under severe external long-term restrictions which prevent the controlling entity from benefiting from its activities' should the controlled entity be excluded form consolidation (IPSAS 6.22).

If control does not exist, it is necessary to investigate whether the decentralised organisation might be a joint venture or associate. According to IPSAS 8.5, a 'joint venture is a binding arrangement whereby two or more parties are committed to undertake an activity which is subject to joint control.' That means that the controlling government or parent of a subgroup cannot decide about the decentralised entity on its own. The entity has joint control over the joint venture together with another venturer. 
IPSAS 7 should be applied for accounting by local government for investments in associates (IPSAS 7.1). Associates are decentralised organisations 'in which the investor has significant influence and which is neither a controlled entity nor a joint venture of the investor' (IPSAS 7.6). Significant influence means the power to influence financial and operating policy decisions of the investee. An investor is supposed to have significant influence if it holds at least $20 \%$ voting power of the investee. If the voting power is about $20 \%$ and significant influence does not exist, it can be proven that the investee is not an associate according to IPSAS 7 . If there are less than $20 \%$ voting rights, a significant influence still exists if the government or parent of a subgroup holds an ownership interest in the other decentralised organisation and the relationship between both organisations shows a significant influence of the investor.

Depending whether control, a joint venture or an associate exists, the consolidation method is determined and therefore the effect of the decentralised organisation will be presented in the consolidated financial statements regarding the influence the local government is able to exercise.

The consolidation methods should represent the different influences the public sector entity has on its subsidiaries. If a public sector entity is under control of another public sector entity, it shall be fully consolidated (IPSAS 6.17). If it is a joint venture, the entity should be consolidated proportionally or by using the equity method (IPSAS 8.36). If a public sector entity has just a significant influence on another public sector entity, the equity method shall be used (IPSAS 7.18). 


\section{Comparative results}

There are several differences between the standards issued by the IPSASB and the SCMA. One obvious difference between the two standard-setters concerns the methods of consolidation. In Table 1 we summarise these differences.

\section{Table 1 Differences in methods of consolidation}

\begin{tabular}{lll}
\hline & IPSASB & SCMA \\
\hline \multirow{3}{*}{ Controlled Entities } & Decision-making approach & Accountability approach \\
& Purchase method & Purchase method \\
Associates & Full consolidation & Proportional consolidation \\
& & Purchase method \\
Joint Ventures & Purchase method & Proportional consolidation \\
& Proportional consolidation & Purchase method \\
& (Equity method) & \\
\hline
\end{tabular}

In the IPSASB standards the concept of control is central. Companies are treated differently, depending on equity interest and the municipality's power to govern the financial and operating policies in the corporation. No corresponding division exists in the SCMA standard. Even if the SCMA standard implies significant influence, the concept of control is not so crucial in the SCMA's standard-setting as in the IPSASB's; instead, economic materiality and obligations are emphasised. In practice this means that according to the IPSASB, several different consolidation methods, full respectively proportional consolidation according to purchase method as well as the equity method, have to be used in the consolidated reporting. According to the SCMA standard, proportional consolidation according to the purchase method should be used, no matter what the equity interest.

Another obvious difference between the standard-setters is that the IPSASB standards are much more comprehensive and detailed than the SCMA standard. 


\section{Conclusions}

\section{Differences in theoretical assumptions - pros and cons}

The IPSASB standards are essentially based on standards issued for the private sector by the IASB (2004). This means that the fundamental feature of the standards is based on a decisionmaking approach that aims to produce information primarily for investors. A negative consequence of this is that the special focus and special needs of the public sector are not sufficiently considered (e.g. Gustavsson, 2004). However, since the majority of the daughter companies have the form of association based on the capitalistic principle of a joint stock company (e.g. Collin and Hansson, 1991), the decision-making approach can in one way seem to be rational and appropriate in the matter of consolidation. But still it is unsatisfactory that IPSASB standard-setting is not based on a comprehensive theoretical framework that explicitly considers the special conditions and needs of public sector accounting information.

The SCMA offers an alternative approach of consolidated reporting which, instead of focusing on future-oriented accounting information, focuses on accounting information useful for accountability relating to employment of resources and obligations. As a consequence, the SCMA standard not only considers consolidation methods and concept of control but also valuation, a topic that IPSASB does not consider in its corresponding standards. However, the SCMA standard is very generally kept and allows scope for different estimates and judgements, something that can have a negative effect on comparability and reliability (e.g. Falkman, 2005). The exception rule that allows the municipality to proceed from the intragroup's annual accounts, even if it is prepared according to the full consolidation method, is a concession towards the accountor, which is not in line with the accountability approach and the interest of the accountee. In practice this exception rule in many cases overturns the fundamental ideas that the standard is based upon, as more and more municipalities organise their ownership and companies in a municipal business group with a 100\%-owned parent company at the top of the group.

In sum: There are several differences between IPSASB and SCMA in their standards for consolidated reporting. The fundamental difference is that the IPSASB standards are based on a decision-making approach while the SCMA standard is based on an accountability approach. Considering organisational goals, financing, ownership and recipients of accounting, several arguments support an accountability approach in public sector accounting. 
However, theoretical arguments also have to be balanced against practical and economical matters. In this balancing act one must also consider national legislation and the scope, aim and direction of the public sector. This comparative study has shown that:

- There are alternative approaches other than the one offered by the international standard-setter.

- Accrual-based public sector accounting does not necessarily have to be based on the decision-making approach.

- The different approaches each have their strengths and limitations. 


\section{References:}

AICPA (American Institute of Certified Public Accountants) (1973). Objectives of Financial Statements. New York: AICPA.

Aiken, M. and McCrae, M. (1992). Full cost pricing and public sector reporting: Alleviating undisclosed short-run measurement biases of 'User to Pay' policies, Financial Accountability and Management, Vol. 8, No. 1, Spring, pp. 13-34.

Alijarde, M. (1997). The usefulness of financial reporting in Spanish local governments, Financial Accountability \& Management, Vol. 13, No. 1, pp. 17-34

Anthony, R.N. (1985). Games government accountants play, Harvard Business Review, Vol. 63, No. 5, pp. 161-170.

Artsberg, K. (1992). Normbildning och redovisningsförändring [Standard setting and accounting change]. Lund: Lund University Press.

Bergevärn, L-E., Mellemvik, F. and Olson, O. (1995). Institutionalization of municipal accounting: A comparative study between Sweden and Norway. Scandinavian Journal of Management, Vol. 11, No. 1, pp. 25-41.

Bouckaert, G. and van Dooren, W. (2003). 'Performance Measurement and Management', in Bovaird, T. and Löffler, E. (Eds.), Public Management and Governance. London: Routledge.

Broadbent, J. and Guthrie, J. (1992). Changes in the public sector: A review of recent 'alternative' accounting research, Accounting, Auditing and Accountability Journal, Vol. 5, No. 2, pp. 3-31.

Brorström, B., Haglund. A. and Solli, R. (2005). Förvaltningsekonomi (Public administration). Lund: Studentlitteratur.

Chan (2003). Government accounting: An assessment of theory, purposes and standards, Public Money and Management, Vol 23, No 1, pp 13 - 20.

Childs, W.H. (1949). Consolidated Financial Statements. New York: Cornell U. Press.

Christensen, M. (2005). The 'third hand': Private sector consultants in public sector accounting change, European Accounting Review, Vol. 14, No. 3, pp. 447-474.

Christiaens, J. (2002). Symposium on local government accounting reforms in Europe: Introduction, Journal of Public Budgeting, Accounting \& Financial Management, Vol. 14 , No. 4, pp. 560-564.

Collin, S-O. and Hansson, L. (1991). Kommunalt Bolag? - För- och nackdelar med bolagisering av kommunalteknisk verksamhet [Municipal corporations - advantages and disadvantages]. Stockholm: Svenska Kommunförbundet.

Coy, D., Dixon, K., Buchanan, J., Tower, G. (1997). Recipients of public sector annual reports: Theory and an empirical study compared, British Accounting Review, Vol. 29, No. 2, pp. 103-127.

Coy, D., Fischer, M., Gordon, T. (2001). Public accountability: A new paradigm for college and university annual reports, Critical Perspectives of Accounting, Vol. 12, No. 1, pp. 1-31.

Daniels, J. and Daniels, C. (1991). Municipal financial reports: What users want, Journal of A.ccounting and Public Policy, Vol. 10, No. 1, pp. 15-38

Demski, J.S., Fellingham, J. C., Ijiri, Y. and Dunder, S. with introduction and concluding remarks by Glover, J.C. and Liang, P. J. (2002). Some thoughts on the intellectual foundations of accounting, Accounting Horizons, Vol. 16, No. 2, pp. 157-168.

Dexia Crediop (2004). Local Public Companies in the 25 Countries of the European Union. Paris: Dexia.

Dittenhofer (2001). Behavioural aspects of government financial management, Managerial Auditing Journal, Vol. 16, No. 8, pp. 451- 457. 
Edström, N-E., Eriksson, O., Grundvall, B., Gustavsson, C-G., Haglund, A., Lagebro, A., Nilsson, A., Nilsson, B-L., Olin, E., Salomon, L., Hjortsberg Sandgren, A. and Tagesson, T. (2004). Årsredovisningarna håller inte måttet [The annual financial statements are not good enough], Dagens Samhälle, No 15.

Eriksson, L. (2002). Koncernredovisning (Consolidated Financial Reporting). Lund: Studentlitteratur.

Falkman, P. (2005). Koncernredovisning i kommuner och landsting - vilka ar problemen [Consolidated reporting in municipalities and county councils - what are the problems?]. Balans, No 10, pp. 38 - 41.

GASB (1987). Concept Statement no. 1 of the Governmental Accounting Standards Board. Stamford, CT: GASB.

GASB (1999). Basic financial statements - and management's discussion and analysis - for state and local governments. Norwalk, CT: GASB.

Gosling, J. J. (1992). Budgetary Politics in American Governments. New York: Longman.

Grossi, G. (2001). Consolidated financial reporting in local governments: A comparative study between Italy and Sweden. Paper presented at the CIGAR Workshop 'Innovations in Governmental Accounting' in Valencia, Spain.

Grossi, G. (2004). Il bilancio consolidato negli enti locali [Consolidated financial statements in local governments], seconda edizione aggiornata. Padova: Cedam.

Grossi, G. and Srocke, I. (2005). Critical analysis of the concept of control according to IPSAS referring to German and Italian local governments, in: Accounting and Performance Management Perspectives in Business and Public Sector Organisations. Bookmill: Tartu, pp. 226-237.

Grönlund, A., Tagesson, T. and Öhman, P. (2005). Principbaserad redovisning. (Principlebased accounting) Lund: Studentlitteratur.

Gustavsson, C-G. (2004). Internationella normer fòr redovisning (International Standards for Accounting). Radet for Kommunal Redovising (SCMA): Stockholm.

Hopwood, A.G. (1984). Accounting and the pursuit of efficiency, in A. Hopwood and C. Tompkins (eds.), Issues in Public Sector Accounting. Oxford: Philip Allan Publ.

Hughes, O. (2004). Public Management \& Administration. London: Macmillan Press.

IASB (2004), International Accounting Standards. London: IASB.

IFAC IPSASB (2005), Handbook of International Public Sector Accounting Standards. New York: IFAC.

Ijiri, Y. (1975). Theory of Accounting Measurement. Saratosa, FL: American Accounting Association.

Ijiri, Y. (1983). On the accountability-based conceptual framework of accounting, Journal of Accounting and Public Policy, Vol. 2, No. 2, pp. 75 - 81.

Jones, R. and Pendlebury, M. (2000). Public Sector Accounting. ( $5^{\text {th }}$ ed.). London: Prentice-Hall.

Jones, R. and Pendlebury, M. (2004). A theory of the published accounts of local authorities, Financial Accountability \& Management, Vol. 20, No. 3, pp. 305325.

Lande, E. (1998). The scope of accounting consolidation in the local public sector, in: Caperchione, E. and Mussari R. (eds.), Comparative Issues in Local Government Accounting (pp. 227-239). London: Kluver.

Lefebvre, C. and Lin, L-Q. (1991). On the scope of consolidation: A comparative study of the EEC $7^{\text {th }}$ directive, IAS 27 and the Belgian Royal Decree on consolidation, British Accounting Review, Vol. 23, No. 2, pp. 133 - 147.

Lüder, K. and Jones, R. (Eds.) (2003). Reforming Governmental Accounting and Budgeting in Europe, Frankfurt am Main: Fachverlag Moderne Wirtschaft. 
Mack, J. and Ryan, C. ( 2006). Reflections on the theoretical underpinnings of the general-purpose financial reports of Australian government departments, Accounting, Auditing \& Accountability Journal, Vol. 19, No. 4, pp. 592-612.

Mattisson, O., Paulsson, G. and Tagesson, T. (2003). Chapter 8: 'Sweden', in Lüder, K. and Jones, R. (Eds.) Reforming Governmental Accounting and Budgeting in Europe. Frankfurt: Fachverlag Moderne Wirtschaft.

Moonitz, M. (1961). The Basic Postulates of Accounting. Accounting Research Study no. 1. New York: AICPA.

Pallot, J. (1992). Elements of a theoretical framework for public sector accounting, Accounting, Auditing \& Accountability Journal, Vol. 5, No. 1, pp. 38-59.

Pina V. and Torres L. (1998). Decentralisation of services and consolidation of annual accounts of local governments. Paper presented at International Conference on Accounting for the New Public Management, Venice, Italy.

Srocke, I. (2004). Consolidated financial accounting of public sector entities according to IPSAS and reform endeavours in Germany. Paper presented at International Conference on Accounting, Auditing and Management in Public Sector Reforms, Oslo, Norway.

Stalebrink, O. J. and Sacco, J. F. (2006). Rationalization of financial statement fraud in government: An Austrian perspective, Critical Perspectives on Accounting, Vol 18, No 4, pp. $489-507$.

Stanton, P, Hughes, J.W., and Stanton, J. (1998). Australian-USA federal governmental accounting: Convergence or divergence?, Financial Accountability \& Management, Vol. 14, No. 4, pp. 249-264.

Svenska Kommunforbundet (1989), Koncernredovisning for kommuner (Consolidated reporting in municipalities). Svenska Kommunforbundet: Stockholm.

Torres L. and Pina V. (2002). Changes in public services delivery in the EU countries, Public Money \& Management, Vol. 22, No. 4, pp. 41-48.

Walker, R.G. (1978). Consolidated Statements. New York: Arno Press.

Walsh K. (1994). The Impact of Competition, Marketing, Competition and the Public Sector: Key Trends and Issues. London: Henry Tam.

Wise V. (2004). Government consolidated financial reporting: harmonisation issues. Paper presented at Business and Economics Society International Conference, Island of Rhodes, Greece.

Wise V. (2006). Cross-transfer of consolidated financial reporting - Conceptual concerns, Australian Journal of Public Administration, Vol. 65, No 3, pp. 62-75.

Zimmerman, J.L. (1977) The municipal accounting maze: an analysis of political incentives, Journal of Accounting Research, Vol. 15 (Supplement), pp. 107 -144. 